\title{
Differences in nitrogen cycling and soil mineralisation between a eucalypt plantation and a mixed eucalypt and Acacia mangium plantation on a sandy tropical soil
}

\author{
Sogni Viviane Tchichelle ${ }^{1,2,3}$, Daniel Epron ${ }^{1,2,3,4}$, Fidèle Mialoundama ${ }^{5}$, Lydie Stella Koutika ${ }^{1}$, Jean-Michel Harmand ${ }^{4}$, \\ Jean-Pierre Bouillet ${ }^{4}$ and Louis Mareschal ${ }^{1,4 *}$ \\ ${ }^{1}$ Centre de Recherche sur la Durabilité et la Productivité des Plantations Industrielles, Pointe-Noire, Republic of the Congo \\ 2 Université de Lorraine, UMR 1137, Ecologie et Ecophysiologie Forestières, Faculté des Sciences, Vandœuvre-lès-Nancy, \\ France \\ 3 INRA, UMR 1137, Ecologie et Ecophysiologie Forestières, Centre de Nancy, Champenoux, France \\ ${ }^{4}$ CIRAD, UMR 111, Ecologie Fonctionnelle et Biogéochimie des Sols et Agro-écosystèmes, Montpellier, France \\ ${ }^{5}$ Université Marien NGouabi, FD-SNA, Faculté des Sciences et Techniques, Brazzaville, Republic of the Congo \\ * Corresponding author, email: louis.mareschal@cirad.fr
}

\begin{abstract}
Sustainable wood production requires appropriate management of commercial forest plantations. Establishment of industrial eucalypt plantations on poor sandy soils leads to a high loss of nutrients including nitrogen (N) after wood harvesting. An ecological intensification of eucalypt plantations was tested with the replacement of half of the Eucalyptus urophylla $\times$ E. grandis by Acacia mangium in the eucalypt monoculture to sustain soil fertility through enhancement of the $\mathrm{N}$ biological cycle. A randomised block design was set up on ferralitic arenosol in the Congolese coastal plains to assess differences in soil $\mathbf{N}$ mineralisation, $\mathbf{N}$ fluxes in litterfall, and $\mathbf{N}$ stocks in forest floor litter and soil between pure acacia (100A), pure eucalypt (100E) and mixed-species treatments (50A50E). Soil $\mathrm{N}$ mineralisation was enhanced under acacia, reaching on average 0.17 and $0.15 \mathrm{mg} \mathrm{kg}^{-1} \mathrm{soil} \mathrm{d}^{-1}$ in $100 \mathrm{~A}$ and $50 \mathrm{~A} 50 \mathrm{E}$, respectively, compared with $0.09 \mathrm{mg} \mathrm{kg}^{-1}$ soil d $\mathrm{d}^{-1}$ in $100 \mathrm{E}$. Higher amounts of $\mathrm{N}$ returning to the soil through harvest residues and litterfall were observed under acacia than under eucalypt. However, $\mathrm{N}$ stock in mineral soil was not increased in $100 \mathrm{~A}$ and exhibited a limited increase only in the top soil layer of 50A50E. Our results suggest a much faster $\mathrm{N}$ turnover under acacia than under eucalypt. Although $A$. mangium is an exotic $\mathrm{N}_{2}$-fixing tree in central Africa, it appears to be well adapted to the climatic and edaphic conditions of the Congo, showing an efficient growth strategy. Eucalypt trees could benefit from the increase in soil $\mathbf{N}$ availability in mixed-species stands.
\end{abstract}

Keywords: ammonium, arenosol, Congo, ecological intensification, forest plantation, mixed species, $\mathrm{N}_{2}$ fixation, nitrate

Introduction

Forest plantations in the tropics are often established on native grasslands or degraded pastures that are generally poor in nutrients (Cossalter and Pye-Smith 2003), especially if the soils are sandy (Martinelli et al. 1999). Eucalyptus is the most widely planted hardwood genus (FAO 2010), but these plantations can have a strong impact on water, carbon and nutrient cycles; their sustainability is a concern also because they are usually harvested every 6-7 years, which entails high nutrient export and has implications for nutrient balance (Laclau et al. 2010). The amount of nitrogen $(\mathrm{N})$ in the soil inherited from prior vegetation can be sufficient to cover tree requirements over the first rotation (Gonçalves et al. 2008; Rothe et al. 2002) but, as $\mathrm{N}$ availability is often a factor limiting eucalypt growth, additional $\mathrm{N}$ input may be required to ensure high and sustainable stand production (Laclau et al. 2010). Fertilisers are therefore often used in commercial eucalypt plantations, but they can be expensive and potentially contribute to water eutrophication (Binkley et al. 1999). Ecological intensification of forest plantation management offers an alternative strategy, and introducing $\mathrm{N}$-fixing species such as acacias into eucalypt stands could be a promising way to ensure their sustainability (Parrotta et al. 1999; Forrester et al. 2005; Kelty et al. 2006). In the Congo, planting Acacia mangium with Eucalyptus can improve stand production in warm humid tropical conditions on nutrient-poor soils by increasing $\mathrm{N}$ soil availability (Bouillet et al. 2013). However, including $\mathrm{N}$-fixing species in mixed-species stands sometimes has a negligible or even negative effect on total production (Forrester et al. 2006; Firn et al. 2007; Bouillet et al. 2013).

Commercial eucalypt plantations have been established in the coastal savanna around Pointe-Noire, Republic of the Congo, since 1978. The soils are sandy, acidic and poor in nutrients (Mareschal et al. 2011; Koutika et al. 2014), and their long-term fertility under eucalypts is a matter of concern. Nitrogen availability, in particular, is the main factor limiting tree growth (Bernhard-Reversat 1996; Nzila et al. 2002), and afforestation led to a deficit of about $110 \mathrm{~kg} \mathrm{~N} \mathrm{ha-1}$ during the first seven-year rotation (Laclau et al. 2005). However, the introduction of acacias into these plantations has been shown to increase soil carbon 
(C) content and $\mathrm{N}$ content, and had a positive effect on wood biomass production in the first rotation (Epron et al. 2013; Koutika et al. 2014). Thus, it appears that associating $A$. mangium and eucalypts in plantations in the Congo may be a promising way of balancing the soil $\mathrm{N}$ budget and improving soil $\mathrm{N}$ availability through $\mathrm{N}_{2}$ fixation and $\mathrm{N}$ recycling.

In this study, we hypothesised that introducing $A$. mangium into $E$. urophylla $\times E$. grandis plantations improves the $\mathrm{N}$ status of the stands on nutrient-depleted soils. The objectives were (1) to estimate $\mathrm{N}$ stocks and $\mathrm{N}$ recycling through litterfall under eucalypt and acacia in both pure and mixed-species treatments, and (2) to quantify soil $\mathrm{N}$ mineralisation and the potential of $A$. mangium for enhancing $\mathrm{N}$ cycling.

\section{Materials and methods}

\section{Study site}

The study site lies about $35 \mathrm{~km}$ from Pointe-Noire city, close to the village of Tchissoko $\left(4^{\circ} \mathrm{S}, 12^{\circ} \mathrm{E}\right.$; altitude $100 \mathrm{~m}$ ), on a deep ferralic arenosol atop a geological bedrock composed of thick detritic layers of continental origin dating from the Plio-Pleistocene. Soils in this area are characterised by very low cation exchange capacity $\left(<0.5 \mathrm{cmol} \mathrm{kg}^{-1}\right)$, high sand content $(>90 \%)$, very low clay and silt content $(6 \%$ and $2 \%$, respectively) and low iron oxide content $(<1.5 \%$ of the bulk soil) (Mareschal et al. 2011). Topsoil $\mathrm{N}$ concentrations in eucalypt stands are typically under $0.05 \%, \mathrm{C}$ concentrations below $1.2 \%$ and $\mathrm{pH}\left(\mathrm{H}_{2} \mathrm{O}\right)$ below 4.6 (Koutika et al. 2014). The topography is slightly undulating. The climate of the coastal plain is characterised by high atmospheric humidity ( $85 \%$ on average, with low seasonal variations of $2 \%$ ) and a mean annual rainfall of about $1200 \mathrm{~mm}$ with a marked dry season from June to September. The mean annual temperature is high $\left(25^{\circ} \mathrm{C}\right)$ with seasonal variations of about $5{ }^{\circ} \mathrm{C}$. During the study, an automatic weather station connected to a data logger (CR1000, Campbell Scientific, Logan, UT, USA) recorded daily rainfall (rain gauge ARG100, Institute of Hydrology, Wallingford, UK) and temperature at the site.

The original vegetation was a native tropical savanna dominated by Loudetia arundinacea (Hochst.) Steud. The savanna was afforested in 1984 with a clone of $E$. saligna, which was harvested in 2003. In May 2004, an experimental trial consisting of a randomised complete block with five replications was established. Each block consisted of three plots of $10 \times 10$ trees (100 trees) at a density of 800 trees ha $^{-1}$ made up of either $100 \%$ A. mangium (100A), $100 \%$ E. urophylla $\times E$. grandis $(100 \mathrm{E})$ or a $1: 1$ mixture of the two species (50A50E) (Epron et al. 2013; Koutika et al. 2014). In the 50A50E treatment, the two species were planted alternately along each row (replacement treatment). The spacing between rows was $3.75 \mathrm{~m}$, with $3.33 \mathrm{~m}$ between the trees in a row. These are current densities used in commercial plantations and are optimal regarding stem wood production in eucalypt monocultures at this site. Glyphosate applications had been used to devitalise the stumps of the previous stand rotation as well as for weed control. A starter fertilisation of $43 \mathrm{~kg} \mathrm{ha}^{-1}$ of $\mathrm{N}$ (as ammonium nitrate) was applied. The trial was harvested in January 2012.
A new trial was planted in March 2012 using the same experimental design and the same species planted at the same locations as previously, just beside the stumps. The starter fertilisation was $150 \mathrm{~kg} \mathrm{ha}^{-1} \mathrm{KCl}$. In order to promote the biological fixation of atmospheric $\mathrm{N}$ by the acacia trees, $\mathrm{N}$ fertilisers were not applied at the beginning of the second rotation, given that high concentrations of $\mathrm{N}$ in the soil may inhibit nodule initiation and specific $\mathrm{N}_{2}$-fixing activity (Streeter 1988). This study was carried out in three of the five blocks.

\section{In situ incubation method}

Net $\mathrm{N}$ mineralisation was monitored monthly from January 2012, just after harvesting the previous stand, until December 2013 in the nine plots (three treatments $\times$ three blocks). Undisturbed soil cores were isolated and incubated in situ inside PVC cylinders $(7.5 \mathrm{~cm}$ in inner diameter and $30 \mathrm{~cm}$ in length), three per plot in 100A and 100E, and six per plot in 50A50E (three in the vicinity of acacia and three in the vicinity of eucalypt trees). The cores were located 25,125 and $250 \mathrm{~cm}$ away along a transect starting from one tree and ending at the centre of the area delimited by four trees (Figure 1) and driven $20 \mathrm{~cm}$ into the soil with a hammer, leaving $10 \mathrm{~cm}$ of the $30 \mathrm{~cm}$ tube above the ground. The cores were incubated for one month with the top of the PVC cylinder covered to avoid lixiviation of mineral $\mathrm{N}$ by rain. Lateral holes under the polyethylene cap allowed the air to circulate. At each sampling date, a non-incubated soil core $(0-20 \mathrm{~cm})$ was also taken from next to each incubated core (i.e. three per plot in $100 \mathrm{~A}$ and $100 \mathrm{E}$, and six per plot in 50A50E) in order to quantify the $\mathrm{N}$ mineral content $\left(\mathrm{NH}_{4}{ }^{+}\right.$plus $\left.\mathrm{NO}_{3}{ }^{-}\right)$of the soil at the beginning of the incubation period (Raison et al. 1987; Voigtlaender et al. 2012). For mineral $\mathrm{N}$ extraction, soils were suspended in $\mathrm{KCl}$ solution (1:5 soil-to-solution, $1 \mathrm{M} \mathrm{KCl}$ ); extracts were analysed for $\mathrm{NO}_{3}{ }^{-}$and $\mathrm{NH}_{4}{ }^{+}$by colorimetry $\left(\mathrm{SAN}^{++}\right.$, Skalar, Breda, The Netherlands).

Net nitrification was calculated as the difference between the final $\mathrm{NO}_{3}{ }^{-}-\mathrm{N}$ content of the soil inside the cylinder at the end of the incubation period and the initial $\mathrm{NO}_{3}{ }^{-} \mathrm{N}$ content of the adjacent soil cores at the beginning of the incubation period. Net $\mathrm{N}$ mineralisation was calculated likewise, using $\left(\mathrm{NH}_{4}{ }^{+} \mathrm{N}+\mathrm{NO}_{3}{ }^{-}-\mathrm{N}\right)$ instead of $\mathrm{NO}_{3}{ }^{-}-\mathrm{N}$.

\section{Soil sampling and soil analyses}

Soil sampling was carried out in December 2011, two weeks before harvest, in the same plots as sampled for $\mathrm{N}$ mineralisation. Sampling was carried out in the central part of each plot to avoid edge effects. In each plot, nine soil samples in $100 \mathrm{~A}$ and $100 \mathrm{E}$ and 18 in 50A50E were collected and separated into four layers $(0-0.05 \mathrm{~m}$, $0.05-0.10 \mathrm{~m}, 0.10-0.15 \mathrm{~m}$ and $0.15-0.25 \mathrm{~m})$ using $5 \times 5 \mathrm{~cm}$ sampling cylinders (Koutika et al. 2014). In 100A and 100E we randomly selected three trees, and in the 50A50E six trees, comprising three acacias and three eucalypts. For each selected tree, we took three soil samples along a transect as described above (Figure 1). The total number of sampling points was 27 in both $100 \mathrm{~A}$ and $100 \mathrm{E}$, and 54 in 50A50E. The soil samples were air-dried and sieved to $2 \mathrm{~mm}$, and root fragments were removed. Bulk density was calculated by dividing the oven-dried soil mass, measured 


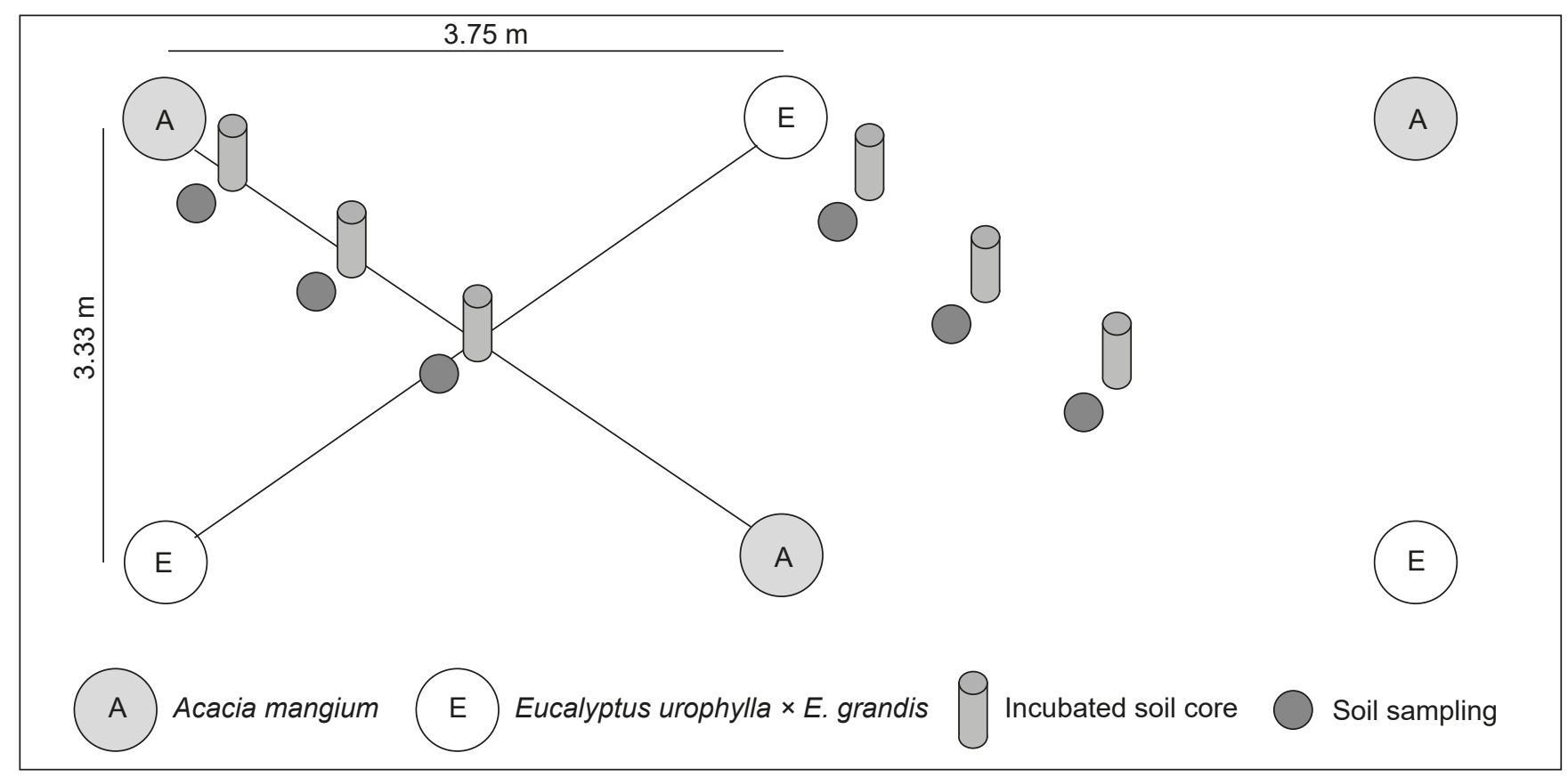

Figure 1: Schematic representation of the soil sampling in the 50A50E treatment and position of the incubated soil cores

on a subsample dried at $105^{\circ} \mathrm{C}$, by the volume of the sampling cylinders. Total $\mathrm{C}$ and $\mathrm{N}$ concentrations were assessed by combustion with an elemental analyser (NCS 2500, Thermoquest, Milan, Italy) and the $\mathrm{N}$ stock in each soil layer was calculated by multiplying the $\mathrm{N}$ concentration by the bulk density and thickness of the soil layer.

\section{Nitrogen in forest floor, harvest residues and litterfall}

Before the 2004-2012 trial was harvested, forest floor litter was collected using a square metallic frame $(50 \mathrm{~cm} \times$ $50 \mathrm{~cm})$ in each treatment. Four (100A, 100E) and six (50A50E) randomly distributed samples were collected in each plot. The samples were oven-dried at $65^{\circ} \mathrm{C}$, weighed and ground before $\mathrm{N}$ analyses.

The mass of bark and leaves left as harvest residues after harvesting was estimated by sampling 10 trees per treatment just before harvesting. The sampled trees were selected so as to be representative of the plot, taking into account the statistical distribution of the cross-sectional area in each treatment, as derived from circumference inventory data. The fresh mass of leaves and bark of the selected trees was measured in the field and subsamples were brought back to the laboratory, oven-dried at $65^{\circ} \mathrm{C}$, weighed and ground before $\mathrm{N}$ analyses. Allometric relationships were then established between the diameter and height of a tree and its mass of leaves and bark, and applied to the plot inventories, thereby estimating the mass of leaves and bark in each plot (see Epron et al. 2013 for the detailed procedure).

After planting the new trial, the above-ground litterfall was collected in traps $(75 \mathrm{~cm} \times 75 \mathrm{~cm})$ placed at the base of the trees and at the centre of the area delimited by four trees. The number of traps was four in the 100A and 100E, and eight in 50A50E. The contents of the traps were collected every week to avoid nitrogen leaching, and the samples pooled per month from June to December 2013. No litterfall occurred before June 2013 because the trees were too young. In the mixed-species stands, the litter collected was sorted according to species. The samples were oven-dried at $65{ }^{\circ} \mathrm{C}$, weighed and ground before analysis.

Nitrogen in litterfall, forest floor and harvest residues was measured on subsamples after combustion in an elemental analyser (NCS 2500, Thermoquest). Nitrogen stocks in forest floor and harvest residues and $\mathrm{N}$ flux in litterfall were calculated by multiplying their $\mathrm{N}$ concentration by their respective dry mass.

\section{Statistical analyses}

Differences between treatments regarding $\mathrm{C}$ and $\mathrm{N}$ concentrations, $\mathrm{N}$ stocks in soil, in forest floor, in harvest residues and soil $\mathrm{N}$ mineralisation were assessed using analysis of variance with a threshold level of $P<0.05$. Homogeneity of variance was tested with Levene's test. Treatment means were compared using Student-Newman-Keuls' multiple range tests (UNISTAT ${ }^{\circledR} 6.5$, UNISTAT, London, UK).

\section{Results}

\section{Nitrogen and carbon}

Harvest residues were significantly greater in both $100 \mathrm{~A}$ and 50A50E than in $100 \mathrm{E}\left(11.3,11.6\right.$ and $7.7 \mathrm{Mg} \mathrm{ha}^{-1}$, respectively) and their $\mathrm{N}$ concentrations significantly higher (two to three times greater) in acacias than in eucalypts: $3.1 \%$ $(100 \mathrm{~A})$ vs $1.6 \%(100 \mathrm{E})$ in leaves, and $1.2 \%(100 \mathrm{~A}) \mathrm{vs}$ $0.37 \%(100 \mathrm{E})$ in bark (Table 1$)$. Nitrogen concentrations in eucalypt harvest residues in 50A50E exhibited lower values than for acacias in the same treatment. Nitrogen stocks in harvest residues were 3.4 and 2.6 times greater in $100 \mathrm{~A}$ and 50A50E, respectively, than in 100E (Table 1). Nitrogen concentrations and stocks on the forest floor differed 
Table 1: Nitrogen concentrations and stocks in harvest residues (leaves and bark), in forest floor litter, soil nitrogen ( $\mathrm{N}$ ) and carbon (C) concentrations, soil $\mathrm{N}$ stocks and soil $\mathrm{C}: \mathrm{N}$ ratios in the soil layers at the beginning of the monitoring in 100A, 100E and 50A/50E treatments. Values are means \pm SE from three replicate blocks. Different letters within a row indicate that means are significantly different $(p<0.05)$. Nitrogen and C concentrations in soil were adapted from Koutika et al. (2014)

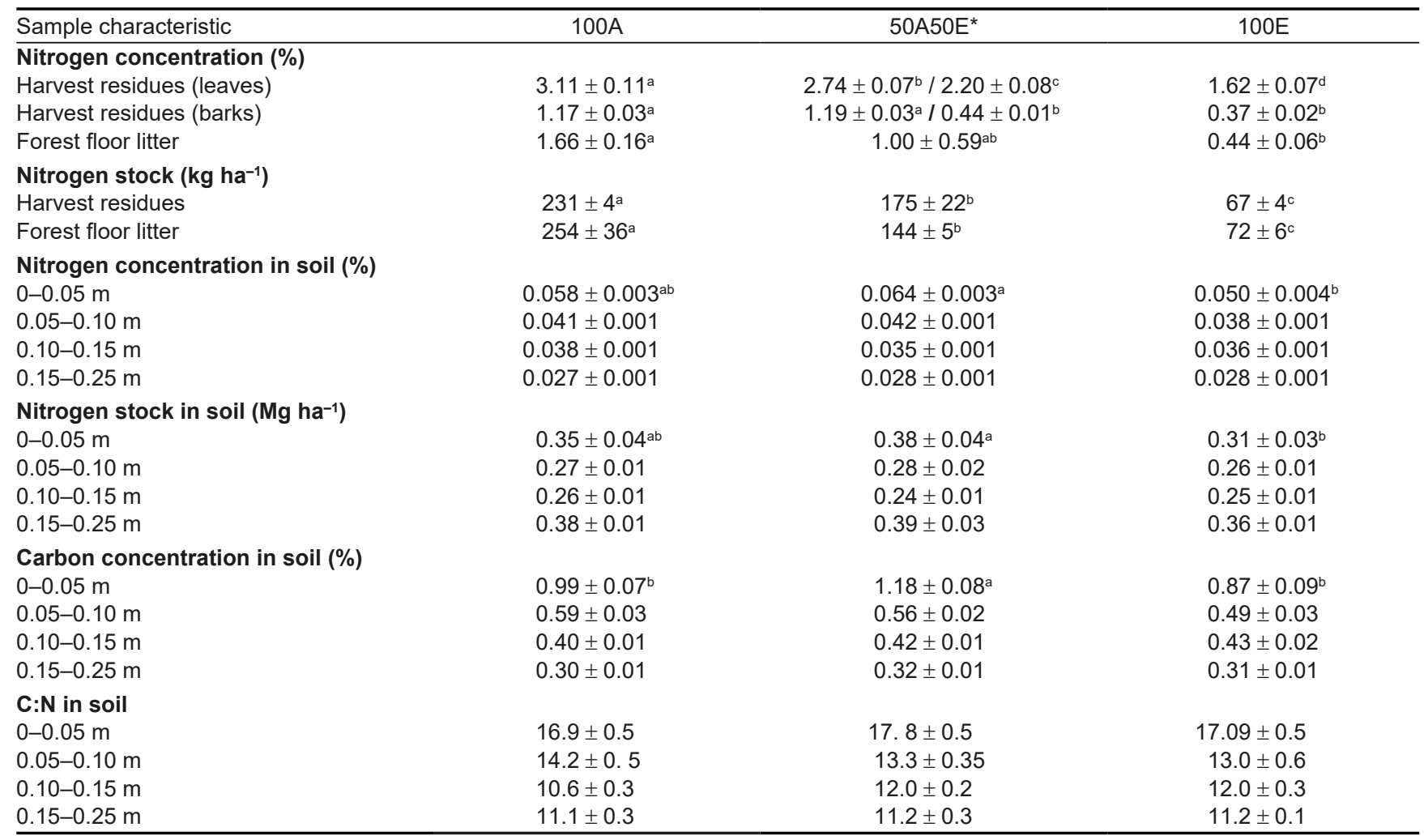

* In the 50A/50E treatment, $\mathrm{N}$ concentrations of harvest residues were measured separately for acacias and eucalyptus

significantly between treatments with higher values in $100 \mathrm{~A}$ than in 100E (Table 1).

Soil $\mathrm{N}$ concentrations decreased with depth, ranging from $0.050-0.064 \%$ in the $0-0.05 \mathrm{~m}$ soil horizon to $0.027-0.028 \%$ in the $0.15-0.25 \mathrm{~m}$ soil horizon. In the uppermost soil horizon, $\mathrm{N}$ concentrations were significantly higher under 50E50E than under 100E, but in lower horizons $\mathrm{N}$ concentrations did not differ between treatments.

Soil $\mathrm{N}$ stocks also decreased with increasing depth in all treatments. They ranged from 0.38 to $0.31 \mathrm{Mg} \mathrm{ha}^{-1}$ in the $0-0.05 \mathrm{~m}$ soil layer, with $100 \mathrm{E} \leq 100 \mathrm{~A} \leq 50 \mathrm{~A} 50 \mathrm{E}$. In this layer, the $\mathrm{N}$ stock under $100 \mathrm{E}$ was not significantly different to that under $100 \mathrm{~A}$ but was significantly lower than that under 50A50E (Table 1). No significant difference was observed between treatments in the deeper soil layers.

Soil $\mathrm{C}$ concentrations decreased with depth, ranging from $1.18-0.87 \%$ in the $0-0.05 \mathrm{~m}$ soil horizon to $0.32-0.30 \%$ in the $0.15-0.25 \mathrm{~m}$ soil horizon, depending on the treatment. The pattern observed was the same as with $\mathrm{N}$ : in the $0-0.05 \mathrm{~m}$ soil horizon, $\mathrm{C}$ concentrations were significantly higher under 50E50E than under 100E, but in lower horizons $\mathrm{C}$ concentrations did not differ between treatments. The $\mathrm{C}: \mathrm{N}$ ratios decreased with increasing depth, ranging from 17 to 18 in the $0-0.05 \mathrm{~m}$ soil layer to 11 in the deeper layers. No significant difference between treatments was observed (Table 1).

\section{Soil net $\mathbf{N}$ mineralisation}

The $\mathrm{N}$ mineral content of the soil increased considerably in the non-incubated soil samples during the first year after replanting, in all treatments (Figure 2a). Values peaked at $45 \mathrm{~kg} \mathrm{ha}^{-1}$ in $100 \mathrm{~A}, 33 \mathrm{~kg} \mathrm{ha}^{-1}$ in 50A50E and $23 \mathrm{~kg} \mathrm{ha}^{-1}$ in $100 \mathrm{E}$. This was followed by a marked decrease of mineral $\mathrm{N}$ in the soil of all treatments, after which, during the second year of monitoring, the amount of mineral $\mathrm{N}$ remained stable and $<14 \mathrm{~kg} \mathrm{ha}^{-1}$. Mineral $\mathrm{N}$ content was significantly greater under 100A than under 100E from January 2012 to August 2012 and from August 2013 to December 2013. During the last four months of the second year, mineral $\mathrm{N}$ content remained significantly greater in 100A than in both other treatments.

During the first year, the maximum monthly rate of $\mathrm{N}$ mineralisation was observed in 50A50E, whereas in the second year it was observed in $100 \mathrm{~A}$ (Figure 2b). Nitrogen mineralisation was significantly greater under 100A than under 100E from January 2012 to March 2012 and from February 2013 to October 2013. Nitrogen mineralisation in $100 E$ never significantly exceeded that under $100 \mathrm{~A}$ and 50A50E over the study period. In all treatments, $\mathrm{N}$ mineralisation decreased in June, July and August, which are the driest and coldest months of the year (Figure $2 b$ and $c$ ). Overall, the seasonal pattern of $\mathrm{N}$ mineralisation reflected the seasonal variations of rainfall and temperature. 


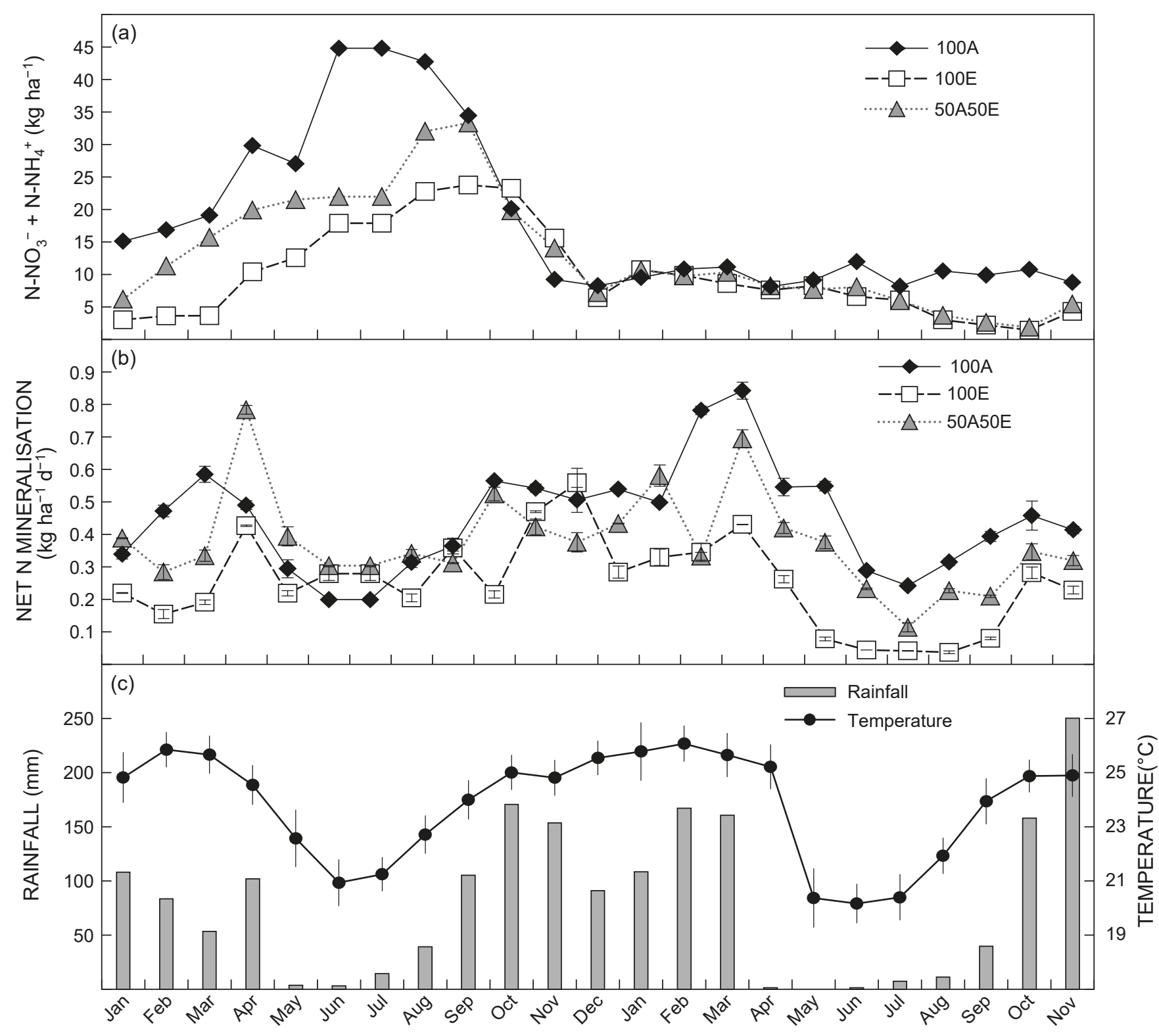

Figure 2: Mineral nitrogen $\left(\mathrm{N}_{-} \mathrm{NO}_{3}{ }^{-}\right.$and $\left.\mathrm{N}-\mathrm{NH}_{4}{ }^{+}\right)$in the $0-20 \mathrm{~cm}$ soil layer at each sampling date in the pure acacia and eucalypt treatments (100A and 100E) and in the mixed-species treatments (50A50E) (a) and N mineralisation in the 0-20 cm soil layer (b) over the study period. Standard errors are indicated by vertical bars $(n=3)$. (c) Monthly rainfall and mean air temperature at the experimental site over the study period; the vertical bars indicate the monthly variation of temperature

The cumulative production of ammonium and nitrate (Table 2) over the study period differed significantly between treatments, with 343,287 and $189 \mathrm{~kg} \mathrm{ha}^{-1}$ in $100 \mathrm{~A}, 50 \mathrm{~A} 50 \mathrm{E}$ and $100 \mathrm{E}$, respectively. The proportion of nitrate produced over the entire study period was similar in all treatments. The $\mathrm{NO}_{3}{ }^{-} /\left(\mathrm{NO}_{3}{ }^{-}+\mathrm{NH}_{4}{ }^{+}\right)$ratio was $0.54,0.56$ and 0.55 in eucalypt, acacia and mixed-species stands, respectively.

\section{Nitrogen in litterfall}

Litterfall mass differed significantly between 100A, 50A50E and $100 \mathrm{E}$, with mean values of $0.48,0.32$ and $0.26 \mathrm{Mg} \mathrm{ha}^{-1}$ month ${ }^{-1}$, respectively. The two species contributed equivalently to the litterfall in 50A50E $\left(0.16 \mathrm{Mg} \mathrm{ha}^{-1}\right.$ month $^{-1}$ each; Figure 3a).
Table 2: Cumulative net production of $\mathrm{N}^{-\mathrm{NH}_{4}}{ }^{+}, \mathrm{N}_{-} \mathrm{NO}_{3}^{-}$and $\mathrm{N}-\mathrm{NH}_{4}{ }^{+}+\mathrm{N}^{-} \mathrm{NO}_{3}^{-}\left(\mathrm{kg} \mathrm{ha}^{-1}\right)$ over two years in the $100 \mathrm{~A}, 100 \mathrm{E}$ and $50 A 50 E$ treatments. Values are means \pm SE from three replicate blocks. Different letters indicate that means are significantly different $(p<0.05)$

\begin{tabular}{lccc}
\hline & $100 \mathrm{~A}$ & $50 \mathrm{~A} 50 \mathrm{E}$ & $100 \mathrm{E}$ \\
\hline $\mathrm{N}-\mathrm{NH}_{4}{ }^{+}$ & $150 \pm 9^{\mathrm{a}}$ & $130 \pm 8^{\mathrm{a}}$ & $87 \pm 6^{\mathrm{b}}$ \\
$\mathrm{N}-\mathrm{NO}_{3}{ }^{-}$ & $193 \pm 12^{\mathrm{a}}$ & $157 \pm 10^{\mathrm{b}}$ & $102 \pm 7^{\mathrm{c}}$ \\
$\mathrm{N}-\mathrm{NH}_{4}{ }^{+}+\mathrm{N}^{-\mathrm{NO}_{3}}{ }^{-}$ & $343 \pm 21^{\mathrm{a}}$ & $287 \pm 17^{\mathrm{b}}$ & $189 \pm 12^{\mathrm{b}}$ \\
\hline
\end{tabular}




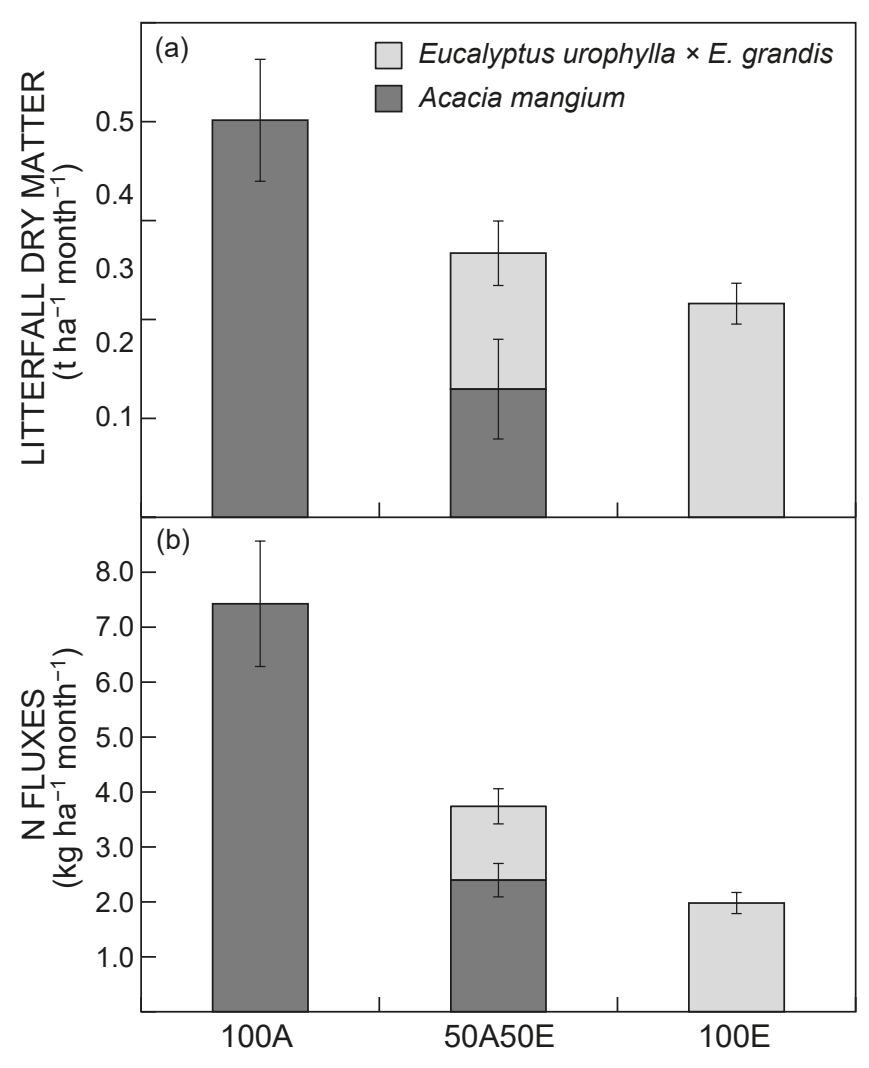

Figure 3: Mean monthly litterfall dry matter (a) and nitrogen fluxes in litterfall (b) in the pure acacia and eucalypt treatments (100A and $100 \mathrm{E})$ and in the mixed-species treatments (50A50E). Vertical bars indicate the SE between blocks $(n=3)$

Nitrogen concentrations in litterfall were twice as high in $100 \mathrm{~A}$ as in $100 \mathrm{E}(1.54 \%$ vs $0.76 \%)$. The amount of $\mathrm{N}$ that returned to the soil through this pathway was 3.8 times higher in $100 \mathrm{~A}$ than in $100 \mathrm{E}\left(7.4 \mathrm{~kg} \mathrm{ha}^{-1} \mathrm{month}^{-1} \mathrm{vs} 2.0 \mathrm{~kg}\right.$ $\mathrm{ha}^{-1}$ month $^{-1}$; Figure $\left.3 \mathrm{~b}\right)$. Nitrogen flux in 50A50E was intermediate $\left(3.7 \mathrm{~kg} \mathrm{ha}^{-1}\right.$ month $\left.^{-1}\right)$.

\section{Discussion}

\section{Changes in nitrogen content of biomass and soil}

The $\mathrm{N}$ stocks in the forest floor and in the harvest residues, quantified when the plantations were harvested at the beginning of the study, were significantly higher under 50A50E and 100A stands than under 100E stands. These $\mathrm{N}$ stocks were directly related to both their dry mass and their $\mathrm{N}$ concentration; the amount of harvest residues was over 1.5 times higher in both 100A and 50A50E than in $100 \mathrm{E}$. This is in line with previous results in this site showing higher growth, higher biomass at harvest and higher leaf area index in 100A and 50A50E than in 100E (Bouillet et al. 2013; Epron et al. 2013). Nitrogen concentrations in harvest residues were two to three times higher than in 100E. This, together with the aforementioned larger amount of harvest residues in the presence of acacias, leads to higher $\mathrm{N}$ stocks left at the end of the first rotation. In the same way, the $\mathrm{N}$ stocks in the forest floor at the end of the first rotation, were 3.8 higher in $100 \mathrm{~A}$ and 2.3 higher in 50A50E than in 100E (Table 1). Thus, the initial stocks of $\mathrm{N}$ in the forest floor plus harvest residues left after the clear cut were 485, 319 and $139 \mathrm{~kg} \mathrm{ha}^{-1}$ in 100A, 50A50E and $100 \mathrm{E}$, respectively. The higher $\mathrm{N}$ concentrations in acacia harvest residues and forest floor compared with eucalypt are explained by the high symbiotic $\mathrm{N}_{2}$ fixation enhanced by soil $\mathrm{N}$ depletion. During the previous rotation, $90 \%$ of the $\mathrm{N}$ content of the acacia biomass in the 50A50E was derived from $\mathrm{N}_{2}$ fixation, with $340 \mathrm{~kg} \mathrm{ha}^{-1}$ of $\mathrm{N}$ fixed over the first 34 months after planting (Bouillet et al. 2013).

Nitrogen stocks in the soil and forest floor were generally greater under $\mathrm{N}$-fixing species than under non- $\mathrm{N}$-fixing species (Rothe et al. 2002; Inagaki et al. 2010; Voigtlaender et al. 2012). Our results agree well with this overall trend, with an amount of $\mathrm{N}$ within the forest floor that was 3.5 times higher in 100A than in 100E, but the fate of $N$ in the forest floor (i.e. mineralisation and uptake) certainly impacts the $\mathrm{N}$ accretion in the mineral soil. Indeed, while the $\mathrm{N}$ stock in the top mineral soil $(0-0.05 \mathrm{~m})$ tended to increase in the presence of acacias, the difference with $100 \mathrm{E}$ was only significant in the $0-0.05 \mathrm{~m}$ soil layer of the treatment $50 \mathrm{~A} 50 \mathrm{E}$. This may be the result of a larger soil $\mathrm{N}$ mineralisation (Table 2) and larger $\mathrm{N}$ uptake in $100 \mathrm{~A}$ than in $50 \mathrm{~A} 50 \mathrm{E}$ given the higher $\mathrm{N}$ concentration in the biomass of acacia trees than that of eucalypt trees (Koutika et al. 2014).

Binkley (2005) showed across 19 case studies that accretion of $1 \mathrm{~g} \mathrm{~N}$ was associated with an average increase of $15 \mathrm{~g} \mathrm{C}$ (range $4-28 \mathrm{~g} \mathrm{C} \mathrm{g}^{-1} \mathrm{~N}$ ) in the soil beneath $\mathrm{N}$-fixing species in pure stands. In the present study, the accretion of $1 \mathrm{~g} \mathrm{~N}$ in the uppermost horizon of the 50A50E treatment was associated with an increase of $22 \mathrm{~g} \mathrm{C}$, which was at the upper end of the range observed in Binkley et al. (2005) in pure species stands. However, the limited increase in $C$ content, evidenced only in the $0-0.05 \mathrm{~m}$ layer in 50A50E, may be explained by the short time since acacia introduction ( 7 years) and by the limited potential of this Congolese sandy soil regarding organic matter (OM) sequestration (Epron et al. 2009; Koutika et al. 2014). This is consistent with Laclau et al. (2010), who observed in nearby eucalypt plantations that the $C$ content of the mineral soil was not significantly affected by contrasted management of organic residues. Sandy soils have lower potential for $\mathrm{OM}$ sequestration than finer-textured soils (Stewart et al. 2008), limiting OM and thus organic $N$ accretion (Martinelli et al. 1999).

\section{Nitrogen mineralisation and cycle}

Our results show that soil $\mathrm{N}$ mineralisation was $82 \%$ higher under $100 \mathrm{~A}$ and $53 \%$ higher under $50 \mathrm{~A} 50 \mathrm{E}$ than under 100E, although differences in $\mathrm{N}$ stock and $\mathrm{C}: \mathrm{N}$ ratio in the $0-25 \mathrm{~cm}$ soil layer between the two pure treatments were not significant. The higher $\mathrm{N}$ mineralisation rate observed under acacias in comparison with eucalypts is consistent with other studies (BernhardReversat 1996; Parrotta 1999; Li et al. 2001; Forrester et al. 2005; Voigtlaender et al. 2012) and reveals a much faster $\mathrm{N}$ cycle in the forest floor and topsoil under $100 \mathrm{~A}$ and 50A50E than under 100E.

It is well known that the rate of litter decomposition, $\mathrm{N}$ mineralisation and nitrification in forest ecosystems is influenced by the quantity and quality of $\mathrm{OM}$, in particular 
the $\mathrm{C}: \mathrm{N}$ and lignin: $\mathrm{N}$ ratios, which vary from species to species (Scott and Binkley 1997; Persson et al. 2000). For example, Andrianarisoa et al. (2010) observed a strong relationship between litterfall $\mathrm{C}: \mathrm{N}$ and nitrification. Given that $\mathrm{N}$ stocks and $\mathrm{C}: \mathrm{N}$ ratios in the mineral soil were not significantly different in $100 \mathrm{~A}$ and $100 \mathrm{E}$, the greater $\mathrm{N}$ mineralisation observed in the mineral soil under acacias could be explained by the preferential mineralisation of recent $\mathrm{N}$-rich $\mathrm{OM}$ from this species. These inputs of recent $\mathrm{OM}$ into the mineral soil could be imputed to leachates of dissolved organic $\mathrm{N}$, particles of $\mathrm{OM}$ from the forest floor and/or the decomposition of acacia fine roots, all of which are likely to be quickly mineralised. Although it is generally assumed that a low $\mathrm{C}: \mathrm{N}$ ratio enhances net $\mathrm{N}$ mineralisation and microbial activity (Berg and Matzner 1997), some studies have shown that the addition of $\mathrm{N}$ to $\mathrm{OM}$ failed to stimulate its decomposition and in some cases even reduced microbial activity (Fog 1988; Michel and Matzner 2002; Craine et al. 2007). Additional studies on OM quality and its biodegradation are necessary to gain a deeper understanding of how the different pools are linked and interact during the process of mineralisation.

The $\mathrm{NH}_{4}{ }^{+} / \mathrm{NO}_{3}{ }^{-}$ratio of mineralized $\mathrm{N}$ in the soil varied little between treatments and averaged 0.82 (ranging from 0.79 to 0.85 ), which is very different from the $\mathrm{NH}_{4}{ }^{+} / \mathrm{NO}_{3}{ }^{-}$ ratios found outside the cylinders, which ranged from 0.8 under acacias to 2.5 under eucalypts. Little is known about the preferential form of mineral $\mathrm{N}$ taken up by the acacias and eucalypts, but the difference in the $\mathrm{NH}_{4}{ }^{+} / \mathrm{NO}_{3}{ }^{-}$ratio with and without root uptake suggests a preferential uptake of $\mathrm{NO}_{3}{ }^{-}$, especially in the case of eucalypt trees. This seems to contrast with the findings of Garnett et al. (2001, 2003), who showed with ion-selective microelectrodes that one-month-old Eucalyptus nitens and E. globulus seedlings had a higher uptake of ammonium than nitrate.

One year after the replantation, the $\mathrm{N}$ concentrations in litterfall collected under acacias were two times higher than those under eucalypts (1.54\% vs $0.76 \%)$. At our site, $\mathrm{N}$ concentration in litterfall of acacias was within the same range that the $\mathrm{N}$ concentrations reported in several studies $(0.7-2.1 \%)$ for this species (Hardiyanto and Wicaksono 2008; Kunhamu et al. 2009; Inagaki et al. 2011; Sugimoto et al. 2013). The $N$ flux back to the soil was 3.8 times greater in 100A than in 100E, and 50A50E exhibited intermediate values (Figure $3 \mathrm{~b}$ ). The contrasting behaviour between $100 \mathrm{~A}$ and $100 \mathrm{E}$ we found in the Congo was more pronounced than that observed in mature stands in Brazil (Voigtlaender et al. 2012), where annual $\mathrm{N}$ flux through litterfall averaged 98, 63 and $49 \mathrm{~kg} \mathrm{ha}^{-1} \mathrm{y}^{-1}$ in $100 \mathrm{~A}, 50 \mathrm{~A} 50 \mathrm{E}$ and $100 \mathrm{E}$, respectively. The values of $\mathrm{N}$ flux in litterfall and of mineralised $\mathrm{N}$ suggest an enhanced $\mathrm{N}$ turnover under acacias compared with eucalypts.

\section{Conclusion}

Comparing soil $\mathrm{N}$ stocks might not be the best way to assess the effect of different tree species on $\mathrm{N}$ cycling rate and soil fertility: in equatorial climates with fast $\mathrm{OM}$ mineralisation, $\mathrm{N}$ returning to the soil through litterfall is more likely to reflect soil $\mathrm{N}$ availability than the $\mathrm{N}$ stocks of the mineral soil.
Introducing Acacia mangium appeared as a promising way to ensure the sustainability of eucalypt plantations established on $\mathrm{N}$-depleted soils. We showed that the $\mathrm{N}$ cycle is much faster in pure acacia and mixed acacia/ eucalypt stands than in pure eucalypt stands. This study therefore suggests that reducing the application of $\mathrm{N}$ fertiliser in eucalypt commercial plantations is possible by capitalising on the facilitation processes at work between the legume trees (or legume understory) and the eucalypts, thereby contributing to maintain soil sustainability. However, more studies are needed on the ecological processes between $\mathrm{N}$-fixing and non- $\mathrm{N}$-fixing trees, focusing in particular on understanding the modalities of $\mathrm{N}$ transfer between tree species, whether via interconnected mycorrhizal networks, biological cycling or exudation.

Acknowledgements - This study benefited from the financial support of the Intens\&fix Project (ANR-2010-STRA-004-03) and the EU-funded ClimAfrica project (7th Framework Programme). The experimental site belongs to the SOERE F-ORE-T, which is supported annually by Ecofor, Allenvi and the French national research infrastructure ANAEE-F (http://www.anaee-france.fr/fr/). SVT's travels to France were financed by CIRAD (AI1). Soil and $\mathrm{N}$ plant analyses were carried out by the Plateforme d'Ecologie Fonctionnelle of UMR EEF in Nancy, France, which is supported by the French National Research Agency through the Laboratory of Excellence ARBRE (ANR-12-LABXARBRE-01)

\section{References}

Andrianarisoa KS, Zeller B, Poly F, Siegenfuhr H, Bienaimé S, Ranger J, Dambrine E. 2010. Control of nitrification by tree species in a common-garden experiment. Ecosystems 13: 1171-1187.

Berg B, Matzner E. 1997. Effect of $\mathrm{N}$ deposition on decomposition of plant litter and soil organic matter in forest systems. Environmental Reviews 5: 1-25.

Bernhard-Reversat F. 1996. Nitrogen cycling in tree plantations grown on a poor sandy savanna soil in Congo. Applied Soil Ecology 4: 161-172.

Binkley D. 2005. How nitrogen-fixing trees change soil carbon. In: Binkley D, Menyailo O (eds), Tree species effects on soils: implications for global change. Dordrecht: Springer. pp 155-164.

Binkley D, Burnham H, Lee Allen H. 1999. Water quality impacts of forest fertilization with nitrogen and phosphorus. Forest Ecology and Management 121: 191-213.

Bouillet J-P, Laclau J-P, Gonçalves JLM, Voigtlaender M, Gava JL, Leite FP, Hakamada R, Mareschal L, Mabiala A, Tardy F, Levillain J, Deleporte P, Epron D, Nouvellon Y. 2013. Eucalypt and acacia tree growth over entire rotation in single-and mixed-species plantations across five sites in Brazil and Congo. Forest Ecology and Management 301: 89-101.

Cossalter C, Pye-Smith C. 2003. Fast-wood forestry myths and realities. Bogor: Center for International Forestry Research.

Craine JM, Morrow C, Fierer N. 2007. Microbial nitrogen limitation increases decomposition. Ecology 88: 2105-2113.

Epron D, Marsden C, M'Bou AT, Saint-André L, d'Annunzio R, Nouvellon Y. 2009. Soil carbon dynamics following afforestation of a tropical savannah with Eucalyptus in Congo. Plant and Soil 323: 309-322.

Epron D, Nouvellon Y, Mareschal L, Moreira RM, Koutika L-S, Geneste B, Delgado-Rojas JS, Laclau J-P, Sola G, Gonçalves JLM, Bouillet J-P. 2013. Partitioning of net primary production in Eucalyptus and Acacia stands and in mixed-species plantations: two case-studies in contrasting tropical environments. Forest Ecology and Management 301: 102-111. 
FAO (Food and Agriculture Organization of the United Nations). 2010. Global forest resources assessment 2010. Key findings. FAO Forestry Paper 163. Rome: FAO.

Firn J, Erskine PD, Lamb D. 2007. Woody species diversity influences productivity and soil nutrient availability in tropical plantations. Oecologia 154: 521-533.

Fog K. 1988. The effect of added nitrogen on the rate of decomposition of organic matter. Biological Reviews 63: 433-462.

Forrester DI, Bauhus J, Cowie AL. 2005. Nutrient cycling in a mixed-species plantation of Eucalyptus globulus and Acacia mearnsii. Canadian Journal of Forest Research 35: 2942-2950.

Forrester DI, Bauhus J, Cowie AL, Vanclay JK. 2006. Mixed species plantations of Eucalyptus with nitrogen-fixing trees: a review. Forest Ecology and Management 233: 211-230.

Garnett TP, Shabala SN, Smethurst PJ, Newman IA. 2001. Simultaneous measurement of ammonium, nitrate and proton fluxes along the length of eucalypt roots. Plant and Soil 236: 55-62.

Garnett TP, Shabala SN, Smethurst PJ, Newman IA. 2003. Kinetics of ammonium and nitrate uptake by eucalypt roots and associated proton fluxes measured using ion selective microelectrodes. Functional Plant Biology 30: 1165-1176.

Gonçalves JLM, Stape JL, Laclau J-P, Bouillet J-P, Ranger J. 2008. Assessing the effects of early silvicultural management on long-term site productivity of fast-growing eucalypt plantations: the Brazilian experience. Southern Forests 70: 105-118.

Hardiyanto EB, Wicaksono A. 2008. Inter-rotation site management, stand growth and soil properties in Acacia mangium plantations in south Sumatra, Indonesia. In: Nambiar SEK (ed.), Site management and productivity in tropical plantation forests: proceedings of workshops in Piracicaba (Brazil) 22-26 November 2004 and Bogor (Indonesia) 6-9 November 2006. Bogor: CIFOR. pp 107-122.

Inagaki M, Kamo K, Miyamoto K, Titin J, Jamalung L, Lapongan J, Miura S. 2011. Nitrogen and phosphorus retranslocation and $\mathrm{N}: \mathrm{P}$ ratios of litterfall in three tropical plantations: luxurious $\mathrm{N}$ and efficient $\mathrm{P}$ use by Acacia mangium. Plant and Soil 341: 295-307.

Inagaki M, Kamo K, Titin J, Jamalung L, Lapongan J, Miura S. 2010. Nutrient dynamics through fine litterfall in three plantations in Sabah, Malaysia, in relation to nutrient supply to surface. Nutrient Cycling in Agroecosystems 88: 381-395.

Kelty MJ. 2006. The role of species mixtures in plantation forestry. Forest Ecology and Management 233: 195-204.

Koutika LS, Epron D, Bouillet J-P, Mareschal L. 2014. Changes in $\mathrm{N}$ and $\mathrm{C}$ concentrations, soil acidity and $\mathrm{P}$ availability in tropical mixed acacia and eucalypt plantations on a nutrient-poor sandy soil. Plant and Soil 379: 205-216.

Kunhamu TK, Kumar BM, Viswanath S. 2009. Does thinning affect litterfall, litter decomposition, and associated nutrient release in Acacia mangium stands of Kerala in peninsular India? Canadian Journal of Forest Research 39: 792-801.

Laclau J-P, Ranger J, Deleporte P, Nouvellon, Y, Saint-André, L, Marlet S, Bouillet J-P. 2005. Nutrient cycling in a clonal stand of Eucalypt and an adjacent savanna ecosystem in Congo 3. Inputoutput budgets and consequences for the sustainability of the plantations. Forest Ecology and Management 210: 375-391.

Laclau J-P, Ranger J, Gonçalves JLM, Maquère V, Krusche AV, M'Bou AT, Nouvellon Y, Saint-André L, Bouillet J-P, Piccolo
MC, Deleporte P. 2010. Biogeochemical cycles of nutrients in tropical Eucalyptus plantations: main features shown by intensive monitoring in Congo and Brazil. Forest Ecology and Management 259: 1771-1785.

Li ZA, Peng SL, Rae DJ, Zhou GY. 2001. Litter decomposition and nitrogen mineralization of soils in subtropical plantation forests of southern China, with special attention to comparisons between legumes and non-legumes. Plant and Soil 229: 105-116.

Mareschal L, Nzila JDD, Turpault MP, M'Bou AT, Mazoumbou JC, Bouillet JP, Ranger J, Laclau JP. 2011. Mineralogical and physico-chemical properties of Ferralic Arenosols derived from unconsolidated Plio-Pleistocenic deposits in the coastal plains of Congo. Geoderma 162: 159-170.

Martinelli LA, Piccolo MC, Townsend AR. Vitousek, PM, Cuevas E, McDowell W, Robertson GP, Santos OC, Treseder K. 1999. Nitrogen stable isotope composition of leaves and soil: tropical versus temperate forests. Biogeochemistry 46: 45-65.

Michel K, Matzner E. 2002. Nitrogen content of forest floor Oa layer affects carbon pathways and nitrogen mineralization. Soil Biology and Biochemistry 34: 1807-1813.

Nzila JDD, Bouillet J-P, Laclau J-P, Ranger J. 2002. The effects of slash management on nutrient cycling and tree growth in Eucalyptus plantations in the Congo. Forest Ecology and Management 171: 209-221.

Parrotta JA. 1999. Productivity, nutrient cycling, and succession in single- and mixed-species plantations of Casuarina equisetifolia, Eucalyptus robusta, and Leucaena leucocephala in Puerto Rico. Forest Ecology and Management 124: 45-77.

Persson T, Rudebeck A, Jussy JH, Colin-Belgrand M, Priemé A, Dambrine E, Karlsson PS, Sjöberg RM. 2000. Soil nitrogen turnover - mineralisation, nitrification and denitrification in European forest soils. In: Schulze ED (ed.), Carbon and nitrogen cycling in European forest ecosystems. Berlin: Springer. pp 297-331.

Raison RJ, Connel MJ, Khanna PK. 1987. Methodology for studing fluxes of soil mineral $\mathrm{N}$ in situ. Soil Biology and Biochemistry 19: 521-530.

Rothe A, Cromack KJ, Resh SC, Makineci E, Son Y. 2002. Soil carbon and nitrogen changes under Douglas-fir with and without red alder. Soil Science Society of America Journal 66: 1988-1995.

Scott N, Binkley D. 1997. Litter quality and annual net N mineralization: comparisons across sites and species. Oecologia 111: 151-159.

Stewart CE, Paustian K, Conant RT, Plante AF, Six J. 2008. Soil carbon saturation: evaluation and corroboration by long-term incubations. Soil Biology and Biochemistry 40: 1741-1750.

Streeter J. 1988. Inhibition of legume nodule formation and $\mathrm{N}_{2}$ fixation by nitrate. CRC Critical Reviews in Plant Sciences 7: $1-23$.

Sugimoto M, Ohta S, Ansori S, Arisman H. 2013. Nutrient dynamics via litterfall and litter decomposition on the forest floor of an Acacia mangium Willd. stand in Sumatra. Tropics 22: 67-81.

Voigtlaender M, Laclau J-P, Gonçalves JLM, Piccolo MC, Moreira MZ, Nouvellon Y, Ranger J, Bouillet J-P. 2012. Introducing Acacia mangium trees in Eucalyptus grandis plantations: consequences for soil organic matter stocks and nitrogen mineralization. Plant and Soil 352: 99-111. 